\title{
Assessment of Respiratory Complications Associated with End Stage Renal Disease in Northern Saudi Arabia
}

\author{
MOHAMMED ABDULRAHMAN S. ALOSAYFIR ${ }^{1}$, FAHAD KHALED FAHAD ALMUZAINI ${ }^{1}$, \\ MOHAMMED FAHAD MOHAMMED ALATEEQ ${ }^{1}$, KHEDER MOHAMED ALTAYEP ${ }^{2}$, \\ HUSSAIN GADELKARIM AHMED ${ }^{1}$ \\ ${ }^{1}$ College of Medicine, University of Hail, Kingdom of Saudi Arabia (KSA) \\ ${ }^{2}$ Department of Medicine, King Khalid Hospital, Hail, KSA
}

\begin{abstract}
Background. The prevalence of End Stage Renal Disease (ESRD) is increasing in different parts of the Kingdom of Saudi Arabia (KSA), particularly Hail Region. Therefore, the aim of this study was to assess the respiratory complications that associated with ESRD.

Methods. In the present study, clinical, imaging and laboratory parameters were identified for 100 ESRD patients with ESRD who were referred to the Pulmonary Medicine Department at King Khalid Hospital.

Results. Pulmonary Edema, Pneumonia, and Pleural effusion were identified in 22\%, 14\%, and $16 \%$ of the referred ESRD patients, respectively.

Conclusion. Respiratory complications are common among ESRD patients in Hail Region.
\end{abstract}

Key words: ESRD, Pulmonary Edema, Pneumonia, Pleural effusion, Saudi Arabia.

\section{INTRODUCTION}

End Stage Renal Disease (ESRD) is a stage of chronic kidney disease (CKD), where dialysis and transplantation are needed [1]. In most instances, CKD is clinically quiet and so undetected until progress to an advanced stage. The prevalence rates of all stages of CKD are high in Hail region, which is relatively similar to those of some western countries with high prevalence of CKD. The prevalence of CKD in the general Saudi population is noticeably high, since there is close homology within Saudi population in different regions [2]. There has been a noticeable escalation in the prevalence of ESRD in KSA over the past 3 decades. The vast and rapid changes in lifestyle, high population growth, and fast increase in life expectancy, and considerable urbanization that has happened over the past 3 decades magnify the burden of CKD. The major risk factors that influence the CKD status are the very high rate of hypertension, diabetes mellitus (DM), Obesity and increase in life expectancy [3-6]. The lungs and kidneys are related to each other, as homeostatic organs controlling the cellular electrolyte and acid-base status. Pulmonary disorders may arise as a direct consequence of renal disease (primary consequences) or through generalized systemic processes [7]. Pulmonary edema that associated with renal disease may occur due to different pathogenic mechanisms. Renal pulmonary edema can be related to excess extracellular fluid accumulation subsequent to impaired water and solute excretion or to an increased pulmonary capillary permeability [8]. Plural effusion can be caused by fluid overload, renal cardiac disease, and pulmonary embolism [9]. Pneumonia is found to complicate at least a third of all episodes of acute renal failure, as well as chronic renal failure, due to profound immune deficits that predispose $[10,11]$.

Therefore, the objective of the current study was to assess the respiratory complications associated with End Stage Renal Disease in Hail region, KSA.

\section{MATERIALS AND METHODS}

This was a descriptive study conducted in King Khalid hospital involving 100 patients, who were previously diagnosed as having ESRD and were referred to the Pulmonary Medicine Department for Respiratory Complications, during the period from January 2015 to January 2016. All medical records of the patients were retrospectively revised with respect to demographical characteristics, ESRD, laboratory data, and comorbid conditions included Diabetes Mellitus, Hypertension, and Anemia.

Diagnosis of respiratory complications was considered if clinical / pulmonary function tests were suggestive and High Resolution CT Scan (HRCT) was consistent of pulmonary condition (Pleural Edema, Pneumonia, and Plural Effusion). Patient's identification data were retrieved from the 
medical records of Kidney failure Department at King Khalid Hospital. Data was retrieved to take information on age, gender, and proved diagnosis of ESRD. Patients without any identifiable cause for pulmonary complications were considered to have idiopathic pulmonary conditions.

\section{DATA ANALYSIS}

Statistical analysis was done using SPSS version 16.0 (SPSS Inc., Chicago, IL, USA). Associations are presented as Odd Ratios (ORs) with their corresponding 95\% confidence intervals (CIs). A value of $p<0.05$ was considered as statistically significant.

\section{ETHICAL CONSENT}

The protocol of the present study was approved by the ethical committee at College of Medicine, University of Hail. The informed consent was agreed about by Pulmonary Medicine Department at King Khalid Hospital.

\section{RESULTS}

This study investigated 100 patients with ESRD, their ages ranging from 18 to 83 years old with a mean age \pm STD $53 \pm 19$ years. Of the 100 patients, 52 were males and 48 were females. Age distribution was relatively similar among males and females.

For respiratory complications; Pulmonary Edema, Pneumonia, and Pleural effusion, were identified in $22 \%, 14 \%$, and $16 \%$ of the referred ESRD patients, respectively. Pulmonary Edema was found in $9 / 52(17.3 \%)$ of males and 13/48(27\%) of females, the risk associated with sex and the 95\% confidence interval $(\mathrm{CI})$, the Odd Ratio $(\mathrm{OR})=$ $0.56(0.22-1.47, \mathrm{P}=0.07)$. Pneumonia was found in $5 / 52(9.6 \%)$ of males and $9 / 48(18.8 \%)$ of females, the risk associated with sex and the $95 \%$ $\mathrm{CI}$, the $\mathrm{OR}=0.46(0.14-1.49, \mathrm{P}=0.15)$. Pleural effusion was found in 5/52(9.6\%) of males and
$11 / 48(22.9 \%)$ of females, the risk associated with sex and the $95 \% \mathrm{CI}$, the OR $=0.46(0.14-1.49, \mathrm{P}=$ $0.06)$, as indicated in Table 1.

Table 2 summarizes the distribution of respiratory complications with age. Respiratory Complications were significantly increasing with the increase of age, the Person's chi square test; $\mathrm{P}<0.001$. The $95 \% \mathrm{CI}$, and the $\mathrm{OR}=22.28$ (5.94 $83.68), \mathrm{P}=0.0001$. The highest number of patients with Pulmonary Edema were found among 66 years and older followed by 56-65 years, representing $9 / 22(40.9 \%)$ and $7 / 22(31.8 \%)$, respectively. The $95 \%$ $\mathrm{CI}$, and the $\mathrm{OR}=\mathbf{2 . 9 5}(1.05$ to 8.35$), \mathrm{P}=0.0408$.

The highest number of patients with Pneumonia were found among age group 56-65 and 66+, each representing $5 / 14(35.7 \%)$. The $95 \% \mathrm{CI}$, and the $\mathrm{OR}=$ $2.5(0.73-8.59), \mathrm{P}=0.1456$.

The highest number of patients with Pleural Effusion were found among age group 56-65 and $66+$, each constituting 6/16(37.5\%). The 95\% CI, and the $\mathrm{OR}=3.15$ (0.94 to 10.55$), \mathrm{P}=0.0 .0633$ as shown in Figure 1.

Table 3 summarizes the Respiratory Complications by Chronic diseases (CDs) and anemia. Of the 100 ESRD patients, there were 84 individuals with some chronic diseases. Of the 84 patients, there were $11 / 84(13 \%), 13 / 84(15.5 \%)$ and $60 / 84$ (71.5\%) with Diabetes Mellitus (DM), hypertension and both DM and hypertension, respectively. Of the 100 patients anemia was identified in $71 / 100(71 \%)$. Of the 11 cases of DM only one patient was identified with Pulmonary Edema. Of the 13 patients with hypertension, 5/13(38.5\%) were identified with Pulmonary Edema, and 3/13 (23\%) with Pneumonia. Of the 60 patients with both hypertension and DM, Pulmonary Edema, Pneumonia and Pleural Effusion were found in $16 / 60(26.7 \%), \quad 10 / 60(16.7 \%)$ and $15 / 60(26 \%)$, respectively. Of the 17 anemic patients, Pulmonary Edema, Pneumonia and Pleural Effusion were found in 17/71(23.9\%), 11/71 (15.5\%) and 12/71(16.9\%), in this order, as shown in Figure 2. Table 4 shows the latest laboratory investigations after the referral to Pulmonary Medicine Department.

Table 1

Respiratory complications by gender

\begin{tabular}{|c|c|c|c|c|c|c|}
\hline Variable & Category & Males & Females & Total & D xalu & OR and $95 \% C I$ \\
\hline \multirow{3}{*}{ Pulmonary edema } & Yes & $9(40.9 \%)$ & $13(59.1 \%)$ & 22 & Pvalue & \multirow{3}{*}{$0.56(0.22-1.47)$} \\
\hline & No & 43 & 35 & 78 & 0.07 & \\
\hline & Total & 52 & 48 & 100 & & \\
\hline \multirow{3}{*}{ Pneumonia } & Yes & $5(35.7 \%)$ & $9(64.3 \%)$ & 14 & 0.15 & \multirow{3}{*}{$0.46(0.14-1.49)$} \\
\hline & No & 47 & 39 & 86 & & \\
\hline & Total & 52 & 48 & 100 & & \\
\hline \multirow{3}{*}{ Pleural effusion } & Yes & $5(31.3 \%)$ & $11(68.7 \%)$ & 16 & 0.06 & \multirow{3}{*}{$0.36(0.11$ to 1.12$)$} \\
\hline & No & 47 & 37 & 84 & & \\
\hline & Total & 52 & 48 & 100 & & \\
\hline
\end{tabular}


Table 2

Respiratory complications by age

\begin{tabular}{|l|c|c|c|c|c|c|c|c|c|}
\hline \multicolumn{1}{|c|}{ Variable } & \multicolumn{3}{c|}{ Pulmonary Edema } & \multicolumn{3}{c|}{ Pneumonia } & \multicolumn{3}{c|}{ Pleural Effusion } \\
\hline \multicolumn{1}{|c|}{ Age } & Yes & No & Total & Yes & No & Total & Yes & No & Total \\
\hline$<30$ years & 4 & 15 & 19 & 2 & 17 & 19 & 1 & 18 & 19 \\
\hline $31-45$ & 0 & 12 & 12 & 2 & 10 & 12 & 1 & 11 & 12 \\
\hline $46-55$ & 2 & 14 & 16 & 0 & 16 & 16 & 2 & 14 & 16 \\
\hline $56-65$ & 7 & 11 & 18 & 5 & 15 & 20 & 6 & 14 & 20 \\
\hline $66+$ & 9 & 26 & 35 & 5 & 28 & 33 & 6 & 27 & 33 \\
\hline Total & 22 & 78 & 100 & 14 & 86 & 100 & 16 & 84 & 100 \\
\hline
\end{tabular}

Table 3

Respiratory complications by chronic diseases (CD) and anemia

\begin{tabular}{|l|c|c|c|c|c|c|c|c|c|}
\hline \multicolumn{1}{|c|}{ Variable } & \multicolumn{2}{c|}{ Pulmonary Edema } & \multicolumn{3}{c|}{ Pneumonia } & \multicolumn{3}{c|}{ Pleural Effusion } \\
\hline Disease & Yes & No & Total & Yes & No & Total & Yes & No & Total \\
\hline DM & $1(9 \%)$ & 10 & 11 & 0 & 11 & 11 & 0 & 11 & 11 \\
\hline Hypertension & $5(41.7 \%)$ & 8 & 12 & $3(23 \%)$ & 10 & 13 & 0 & 13 & 13 \\
\hline DM and hypertension & $16(26.7 \%)$ & 44 & 60 & $10(16.7 \%)$ & 50 & 60 & $15(25 \%)$ & 45 & 60 \\
\hline No CD & 0 & 16 & 16 & $1(6.3 \%)$ & 15 & 16 & $1(6.3 \%)$ & 15 & 16 \\
\hline Anemia & $17(23.9 \%)$ & 54 & 71 & $11(15.5 \%)$ & 60 & 71 & $12(16.9 \%)$ & 59 & 71 \\
\hline
\end{tabular}

Table 4

Respiratory complications by latest laboratory investigations

\begin{tabular}{|l|c|c|c|c|}
\hline \multicolumn{1}{|c|}{ Variable } & Category & Pulmonary Edema & Pneumonia & Pleural Effusion \\
\hline Urea & High & $24.7 \%$ & $14 \%$ & $16.5 \%$ \\
\hline Uric acid & High & $22.7 \%$ & $13.4 \%$ & $16.5 \%$ \\
\hline Creatinine & High & $22 \%$ & $14 \%$ & $16 \%$ \\
\hline \multirow{2}{*}{ Sodium } & Low & $22.2 \%$ & $0 \%$ & $0 \%$ \\
\hline \multirow{2}{*}{ Potassium } & Low & $0 \%$ & $0 \%$ & $0 \%$ \\
\cline { 2 - 5 } & High & $9 \%$ & $9 \%$ & $0 \%$ \\
\hline \multirow{2}{*}{ Chloride } & Low & $12.5 \%$ & $25 \%$ & $0 \%$ \\
\hline \multirow{2}{*}{ Calcium } & High & $0 \%$ & $0 \%$ & $0 \%$ \\
\cline { 2 - 5 } & Low & $23 \%$ & $26.9 \%$ & $7.7 \%$ \\
\cline { 2 - 5 } & High & $0 \%$ & $0 \%$ & $0 \%$ \\
\hline
\end{tabular}

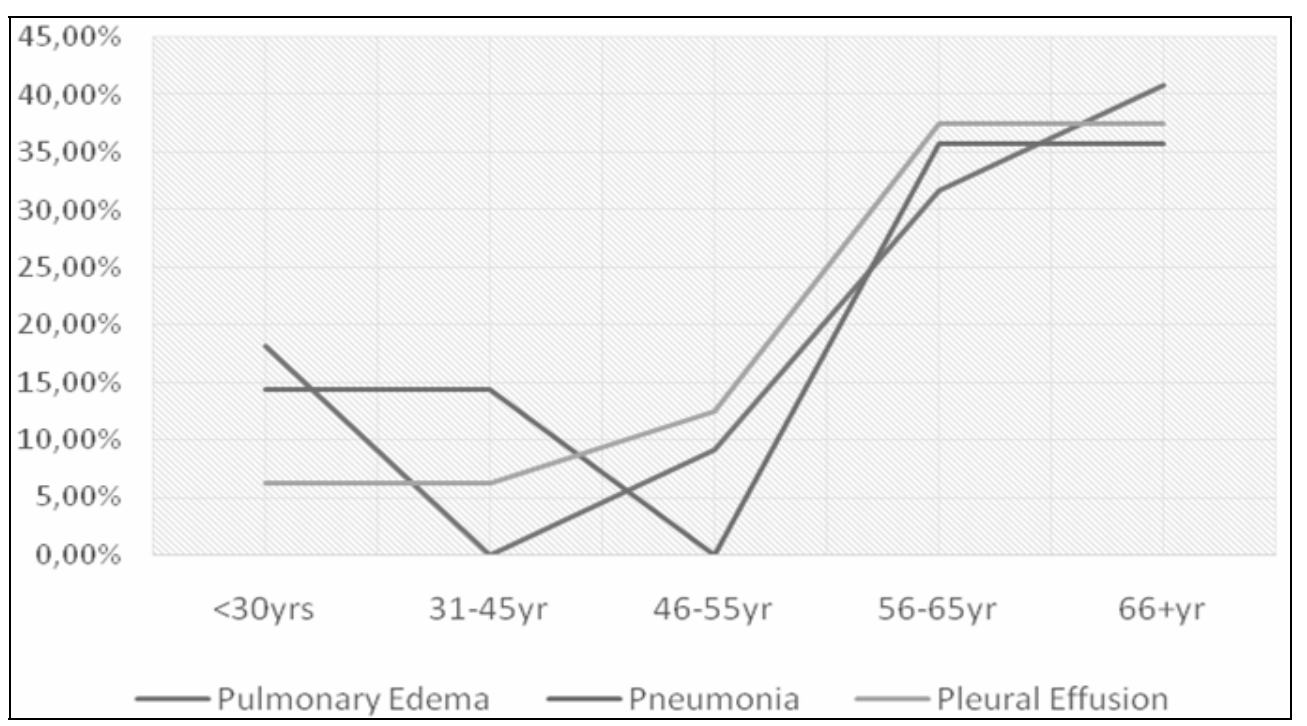

Figure 1. Respiratory complications by age. 


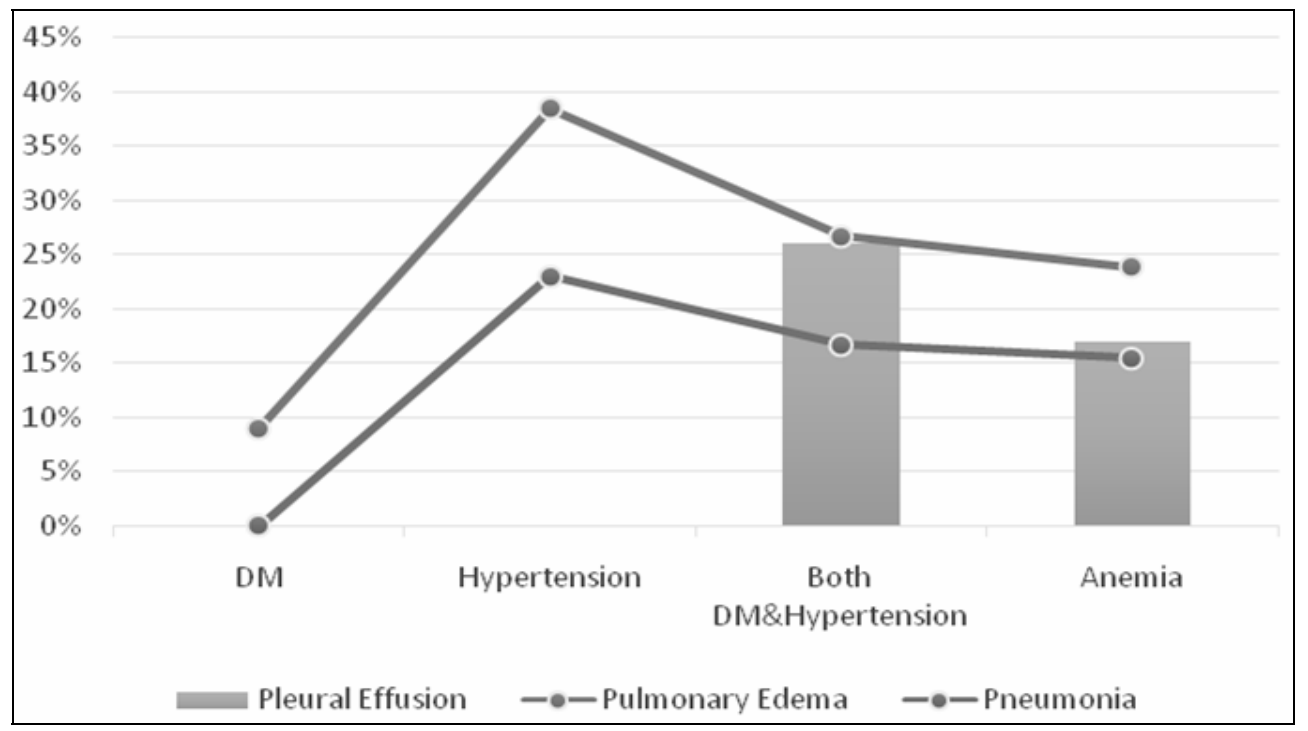

Figure 2. Respiratory complications by chronic diseases (CD) and anemia.

\section{DISCUSSION}

This study reported considerable proportions of respiratory complications among patients with ESRD with predominately Pulmonary Edema affecting $22 \%$ of the patients. Variable proportions of pulmonary edema have been reported in several studies. Pulmonary edema was previously reported in $36 \%$ of the cases with ESRD [12], which is very high from our findings. This variation may be due to the high cardiovascular risk profile of individuals with CKD, in that study, which was not similar to our study population, since cardiovascular disease was an important cause of pulmonary edema [13]. However, there are several factors associated with occurrence of pulmonary edema which were not assessed in the present study including high blood pressure $(29 \%)$, rapid atrial fibrillation (29\%) unstable angina pectoris (25\%), infection (18\%), and acute myocardial infarction (15\%) [14].

Pneumonia was identified in $14 \%$ of our study population which was far less of some reports which indicated its presence in $26 \%$ of the cases with CKD [12]. Infection is one of the most common causes of morbidity and mortality in patients with CKD in many populations [15]. The complicated associations between $\mathrm{CKD}$, infection, and cardiovascular diseases limit explanation of the direction of any causal association between CKD and infection [16]. The risk of hospitalization and death with pneumonia is greater at lower eGFRs, which may contribute to increased mortality in patients with CKD [17].
Pleural effusion was identified in $16 \%$ of the patients in the present study. Pleural effusions encountered in patients with CKD may result from diverse causative factors that may differ from certain population to another. Therefore, there might be variable incidence rates in different countries. Incidence of $6.7 \%$ was previously reported in patients with CKD [18].

In regard to the relation between age and proportions of respiratory complications, all categories were seemed to increase among females, but without statistically significant differences (Figure 1).

The frequencies of all three respiratory complications were found to increase with age and with statistically significant differences. CKD is the most common in elderly individuals. Declining in renal function with age was well established in many studies [19-22]. In the elderly individuals the glomerular filtration rate (GFR) reduces in each year. This differs between individuals, however it was demonstrated that the average decline in GFR is estimated at $1 \mathrm{~mL} / \mathrm{min} / 1.73 \mathrm{~m}^{2}$ per year [23]. This in addition to the presence of comorbidities such as diabetes, hypertension significantly associated with elderly. As the mean age of all populations is continuously increasing, decreasing the risk of $\mathrm{CKD}$ in the elderly persons is one of the most important challenge of the future era. Therefore, elderly people were more susceptible for respiratory complications than the younger ones.

There is high rate of comorbid conditions, particularly DM and Hypertension, which represent major risk factors for the occurrence of CKD [24]. 
Presence of comorbid conditions with CKD are important factors for the occurrence of respiratory complications, especially pneumonia. Although, DM is a frequent comorbid condition among patients with pneumonia living in the community [25], but in the present study showing inverse association. Comorbidities of patients with $\mathrm{CKD}$, including DM, cardiovascular disease (CVD), asthma, and chronic obstructive pulmonary disease (COPD), were independently associated with increased risk of pneumonia [26]. Patients receiving renal replacement therapy may be at increased infection risk due to their treatment.

A reasonable number of patients in this study were found with anemia. Anemia is common in patients with ESRD [27], due to impaired production of renal erythropoietin [28].

The strengths of the present study include the addition of more evidence to existing literature from Saudi Arabia. In addition this study provides new insights for Local Health Care Provider regarding pulmonary comorbidities of ESRD, thus stimulating future research in this area.

The study has some limitations, such as the nature of the collected data; information regarding ESRD were collected from patients' files, missing of detailed information regarding infections and subsequent patients' management.

In conclusion, the most common respiratory complications among ESRD patients in Hail are Pulmonary Edema, pneumonia and Plural Effusion. Most Respiratory complications occur in elderly patients with relatively increased proportions among females. Most of the patients were with comorbid conditions such as DM, hypertension and anemia.

Acknowledgement. Authors would like to thank people at Pulmonary Medicine Department in King Khalid Hospital, Hail, KSA.

Conflict of interest. The authors declare no conflict of interest.

Introducere. Prevalența bolii renale cronice terminale (ESRD) este în creştere în majoritatea regiunilor din Arabia Saudită, mai ales în regiunea Hail. De aceea, scopul studiului a fost de a evalua complicațiile respiratorii asociate ESRD.

Materiale şi metode. Au fost analizați parametrii clinici, imagistici şi de laborator la 100 de pacienți cu ESRD care s-au prezentat la departamentul de pneumologie al spitalului King Khalid.

Rezultate. Edemul pulmonar, pneumonia şi revărsatul pleural au fost identificate la $22 \%, 14 \%$ şi respectiv $16 \%$ dintre pacienți.

Concluzii. Complicațiile respiratorii sunt relativ frecvente la pacienții cu ESRD din regiunea Hail.

Correspondence to: Prof. Hussain Gadelkarim Ahmed, College of Medicine,

University of Hail, 2440, KSA, phone: +966502609300

E-mail: hussaingad1972@yahoo.com

\section{REFERENCES}

1. ZOCCALI C, KRAMER A, JAGER KJ. Chronic kidney disease and end-stage renal disease - a review produced to contribute to the report 'the status of health in the European Union: towards a healthier Europe'. NDT Plus 2010; 3 (3): 213-224.

2. AHMED HG, GINAWI IA, AL-HAZIMI AM. Prevalence Estimates of Chronic Kidney Disease in Hail Region, KSA: in a Comprehensive Survey. International Journal of Science and Research 2014; 3(7): 252-56.

3. AL-SAYYARI AA, SHAHEENFA. End stage chronic kidney disease in Saudi Arabia. A rapidly changing scene. Saudi Med J. 2011; 32(4):339-46.

4. AHMED HG, GINAWI IA, AL-HAZIMI AM. Prevalence of Hypertension in Hail Region, KSA: in a Comprehensive Survey. International Journal of Sciences: Basic and Applied Research (IJSBAR) 2014; 17(2): 288-296.

5. AHMED HG, GINAWI IA, ALSHAMMRI FD, ELASBALI AM, ALTOM FM, AL-HAZIMI AM. Current Burden of diabetes in Kingdom of Saudi Arabia in an epidemiological survey. Egypt. Acad. J. Biolog. Sci. 2014; 6(2): 85- 91.

6. AHMED HG, GINAWI IA, ELASBALI AM, ALTOM FM, ASHANKYTY IM, AL-HAZIMI AM. Prevalence of Obesity in Hail Region, KSA: In a Comprehensive Survey. Journal of Obesity 2014; 2014, Article ID 961861, 5 pages.

7. HASSAN IS, GHALIB MB. Lung Disease in Relation to Kidney Diseases. Saudi J Kidney Dis Transpl 2005; 16:282-7.

8. HUNG J, HARRIS PJ, UREN RF, TILLER DJ, KELLY DT. Uremic cardiomyopathy-effect of hemodialysis on left ventricular function in end-stage renal failure. N Engl J Med. 1980; 302(10):547-51. 
9. NIDUS BD, MATALON R, CANTACUZINO D, EISINGER RP. Uremic pleuritis - a clinico-pathological entity. N Engl J Med 1969; 281(5):255-6.

10. MCMURRAY SD, LUFT FC, MAXWELL DR, HAMBURGER RJ, FUTTY D, SZWED JJ, et al. Prevailing patterns and predictor variables in patients with acute tubular necrosis. Arch Intern Med 1978; 138(6):950-5.

11. SARNAK MJ, JABER BL. Pulmonary infectious mortality among patients with end-stage renal disease. Chest 2001; 120(6):1883-7.

12. HALLE MP, HERTIG A, KENGNE AP, ASHUNTANTANG G, RONDEAU E, RIDEL C. Acute pulmonary oedema in chronic dialysis patients admitted into an intensive care unit. Nephrol. Dial. Transplant. 2012; 27 (2): 603-607.

13. LEVIN A. Clinical epidemiology of cardiovascular disease in chronic kidney disease prior to dialysis. Semin Dial. 2003; 16:101-105.

14. YEOUDA E, ARIEL R, DORON B, SHIMON RA. Prospective evaluation of pulmonary edema. Crit Care Med 2000; $28: 330-335$.

15. VIASUS D, GARCIA-VIDAL C, CRUZADO JM, ADAMUZ J, VERDAGUER R, MANRESA F, et al. Epidemiology, clinical features and outcomes of pneumonia in patients with chronic kidney disease. Nephrol Dial Transplant. 2011; 26(9):2899-906.

16. MCDONALD HI, THOMAS SL, MILLETT ER, NITSCH D. CKD and the risk of acute, community-acquired infections among older people with diabetes mellitus: a retrospective cohort study using electronic health records. Am J Kidney Dis. 2015; 66(1):60-8.

17. JAMES MT, QUAN H, TONELLI M, MANNS BJ, FARIS P, LAUPLAND KB, et al. CKD and risk of hospitalization and death with pneumonia. Am J Kidney Dis. 2009; 54(1):24-32.

18. RAY S, MUKHERJEE S, GANGULY J, ABHISHEK K, MITRAS S, KUNDU S. A cross-sectional prospective study of pleural effusion among cases of chronic kidney disease. Indian J Chest Dis Allied Sci. 2013; 55(4):209-13.

19. EPSTEIN M. Aging and the kidney. J Am SocNephrol. 1996; 7(8):1106-22.

20. GLASSOCK RJ, RULE AD. The implications of anatomical and functional changes of the aging kidney: with an emphasis on the glomeruli. Kidney Int. 2012; 82(3):270-7.

21. KIM JH, HWANG KH, PARK KS, KONG ID, CHA SK. Biological Role of Anti-aging Protein Klotho. J Lifestyle Med. 2015; $5(1): 1-6$.

22. ORCHARDSON RL. Renal function and age. J Coll Gen Pract. 1966; 12(3):285-92.

23. WESSON LG. Physiology of the human kidney. Grune \& Straton, New York, 1969: 96.

24. GINAWI IA, ELASBALI AM, AHMED HG, ASHANKYTY IM, ALTAMIMI T, ALHASAN SM, et al. Population screening for chronic kidney disease and its associated risk factors: a survey in Hail region, KSA. J. Public Health Epidemiol 2013; 5(7): 285-90.

25. FALCONE M, TISEO G, RUSSO A, GIORDO L, MANZINI E, BERTAZZONI G, et al. Hospitalization for pneumonia is associated with decreased 1-year survival in patients with type 2 diabetes: results from a prospective cohort study. Medicine (Baltimore). 2016; 95(5):e2531.

26. CHOU CY, WANG SM, LIANG CC, CHANG CT, LIU JH, WANG IK, et al. Risk of pneumonia among patients with chronic kidney disease in outpatient and inpatient settings: a nationwide population-based study. Medicine (Baltimore) 2014; 93(27): 174.

27. KIM SM, KIM KM, KWON SK, KIM HY. Erythropoiesis-stimulating agents and anemia in patients with non-dialytic chronic kidney disease. J Korean Med Sci. 2016; 31(1):55-60.

28. DE SEIGNEUX S, LUNDBY AM, BERCHTOLD L, BERG AH, SAUDAN P, LUNDBY C. Increased synthesis of liver erythropoietin with CKD. J Am Soc Nephrol. 2016; 12. pii: ASN.2015050508. [Epub ahead of print]

Received May 10, 2016 